TURIZAM

Volume 23, Issue 1

53-68 (2019)

ORIGINAL

SCIENTIFIC PAPER

\section{Speleological Approach for Geotourism Development in Zlatibor County (West Serbia)}

\author{
Stojan VukovićA , Aleksandar Antić A* $^{*}$ \\ Received: April 2019 | Accepted: May 2019 \\ DOI: 10.5937/turizam23-21325
}

\begin{abstract}
Western Serbia is a part of the Dinaric karst, which makes this area rich with caves, karst springs, karst waterfalls and other karst phenomena. Caves in the Zlatibor county, as representative speleological geosites, are one of the first established tourist caves in Serbia. They have great potential for speleotourism and geotourism development in the region and are considered important for tourism development of Zlatibor mountain. In this paper we analyze the speleological potential for geotourism development in Zlatibor county (west Serbia). The main goal of the paper was to determine the current state of speleotourism in Zlatibor county and possibilities for further development by analyzing two caves in this area: Stopića cave and Potpećka cave. Our research was carried out by applying the Modified Geosite Assessment Model (M-GAM). The results show that these caves are not just favourable geosites with great complementary tourism potential of the Zlatibor mountain, but they are also unique speleological objects with vast speleotourism and geotourism development opportunities.
\end{abstract}

Keywords: caves, geotourism, Zlatibor, West Serbia.

\title{
Introduction
}

Speleotourism, or cave tourism, is a recent area evolving in the spectrum of possibilities for tourism in natural areas (Lobo, Moretti, 2009). Speleothems (stalagmites, stalactites, etc.) have long drawn tourists to visit limestone caves throughout the world and as a result many public show-caves have been established in the $2 \mathrm{O}^{\text {th }}$ century (Baker, Genty, 1998). The caves are places where visitors can learn about geology and conservation (Newsome, Dowling, 2006), but they are also important for sustainable development of local and regional communities (Dowling, 2013). Speleotourism should only be considered successful if local communities have some measure of control over them and if they share equitably in the benefits emerging from geotourism and speleotourism opportunities (Dowling, 2013).

Serbia is a country with very rich geodiversity existing in numerous forms (Đurović, Mijović, 2006). The geological diversity of karst regions in Serbia can bring a new level of under-

A University of Novi Sad, Faculty of Sciences, Department of Geography, Tourism and Hotel Management, Trg Dositeja Obradovića 3, 21000 Novi Sad, Serbia; Corresponding author: a.antic994@gmail.com 
standing about the natural heritage (Višnić, Began, 2015) and thus influence on the development of geotourism and speleotourism as its part. In Serbia, many caves are unexplored and not arranged for tourist visitation. Therefore, it is important to mention some of the studies that focus on the successful development of tourist caves. Russel and Jeanne Gurnee (1981) presented the combination of four factors that are crucial for successful development and operation of a tourist cave. These factors are: scientific investigation, art, technology and management. Cigna and Burri (200o) recommended the scientific study at the beginning of the first phase of cave exploration. Art is necessary both in determining the routing of trails and selecting which cave scenes to feature. Lighting is a combination of both art and the next factor, technology. The technology is necessary to control water and other natural forces within the cave and to design suitable trails. Management is the process that continues from the time the first plans are laid through the development and operational phase.

Karst regions in Serbia have great potential for speleotourism development. Caves could have a major role on the national tourist market, thus bringing more tourists and influencing the tourist income. It is necessary to continually monitor speleotourism trends throughout the world so that caves in Serbia can be competitive on this market. The uniqueness of these caves certainly provides a possibility for their exploration and recognition (Tomić et al., 2019).

In this paper we analyze the speleotourism potential in Zlatibor county (West Serbia). The two caves, that were evaluated, are Stopića cave and Potpećka cave. Both caves are located near the Zlatibor mountain, which makes them a part of the Dinaric karst region. The main goal of the paper was to determine the current state of speleotourism in Zlatibor county and possibilities for further development. Our research was carried out by applying the Modified Geosite Assessment Model (M-GAM) created by Tomić and Božić (2014). The results of the geosite assessment should provide information about current main and additional values. Based on those pieces of information we can determine the possibilities for further development of speleotourism in this area.

\section{Study area}

The region of West Serbia is a karst area with plenty of caves and other karst features. However, due to the different nature of karst, this region has fewer caves open for tourist visits than Eastern Serbia. The two analyzed caves in this paper were selected as the most representative and the only two caves adapted for tourist visits in West Serbia.

Stopića cave. This monument of nature lies on the north-eastern side of Zlatibor mountain, in Western Serbia. Zlatibor - Sirogojno road is located above it. It is located $250 \mathrm{~km}$ from Belgrade, $30 \mathrm{~km}$ from Užice, $19 \mathrm{~km}$ from the Zlatibor tourist center, and $3.5 \mathrm{~km}$ from the ethno-village Sirogojno.

The Stopića cave is a river type cave, because the Trnava stream passes through the cave. It represents the underground extension of the Trnava stream, which flows into the upper opening of the Stopića cave. After a short flow of 117 meters, the cave river is joining the waters of Prištevica, the left tributary of Veliki Rzav river. The entrance to the Stopića cave lies at a height of $776.96 \mathrm{~m}$. The cave has an impressive entrance with an $18 \mathrm{~m}$ high and $35 \mathrm{~m}$ wide opening. The surface of the cave is $7.911 .5 \mathrm{~m}^{2}$ and has a volume of $120.000 \mathrm{~m}^{3}$, of which length of $1.691 \mathrm{~m}$ is arranged for tourist visits. The limestone layer in the cave dates from the Triassic period and is over $100 \mathrm{~m}$ thick. The climate in the cave is influenced by the external climate (Čumić, 2010). 


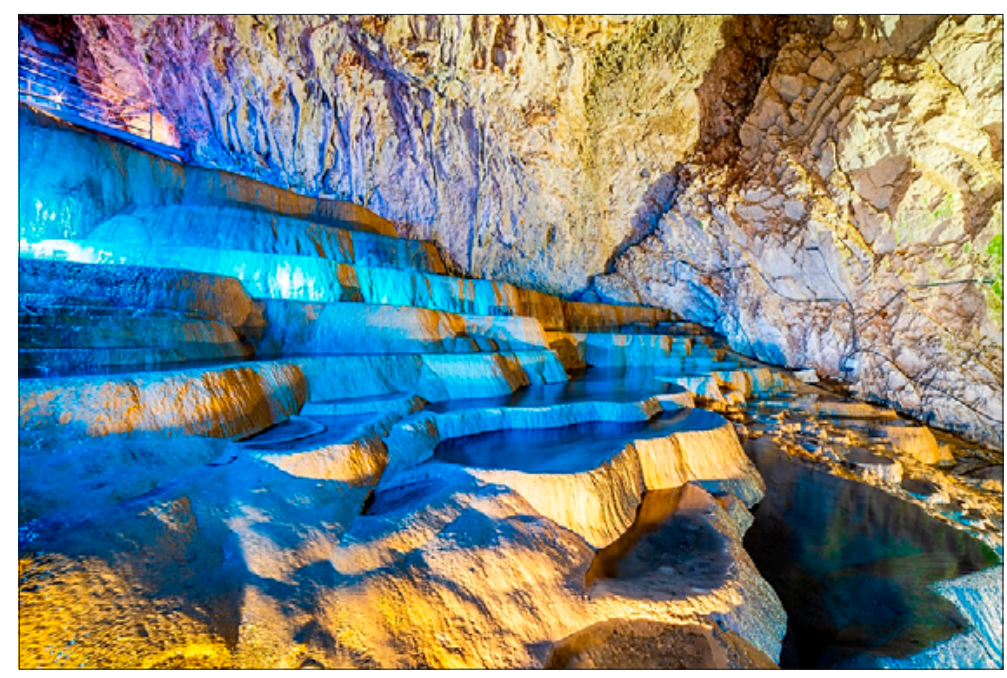

Figure 1. Stopića cave (Rimstone pools) Source: S. Vuković

The Stopića cave consists of five parts: The Bright Hall, the Dark Hall, the Great Hall with rimstone pools, a canal with pools and River canal. The tourist part of the cave has several attractive elements, such as: a spacious entrance, waterfall and a series of rimstone pools.

Rimstone pools, in their uniqueness, represent the trademark of the cave, formed by the deposition of limestone. They are dents bordered with the stone walls, i.e. the sinuous, reddish rimstone wrinkles in which the water accumulates and thus cascading from the pool.

Potpećka cave. This cave is located in Potpeć village, $14 \mathrm{~km}$ southeast of Užice. It is unique with its monumental entrance. The entrance height is $50 \mathrm{~m}$, while the width is $12 \mathrm{~m}$. The arranged length of the tourist trail in the cave is $555 \mathrm{~m}$. The entry-descending path has over

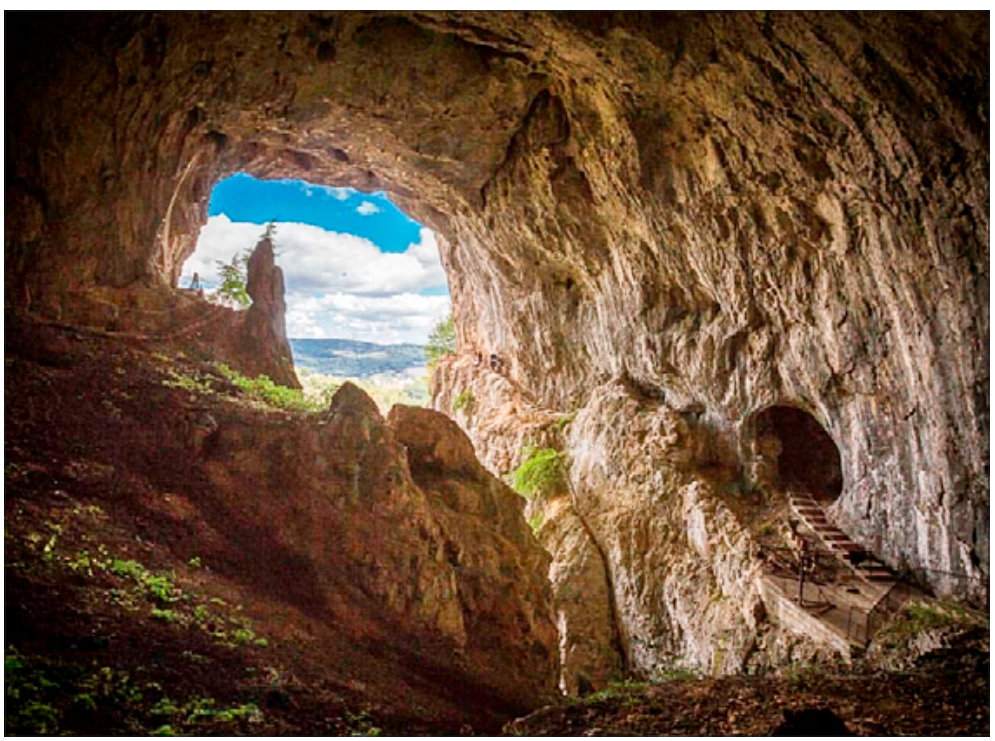

Figure 2. Potpećka cave

Source: $\bigoplus$. Nikolić 


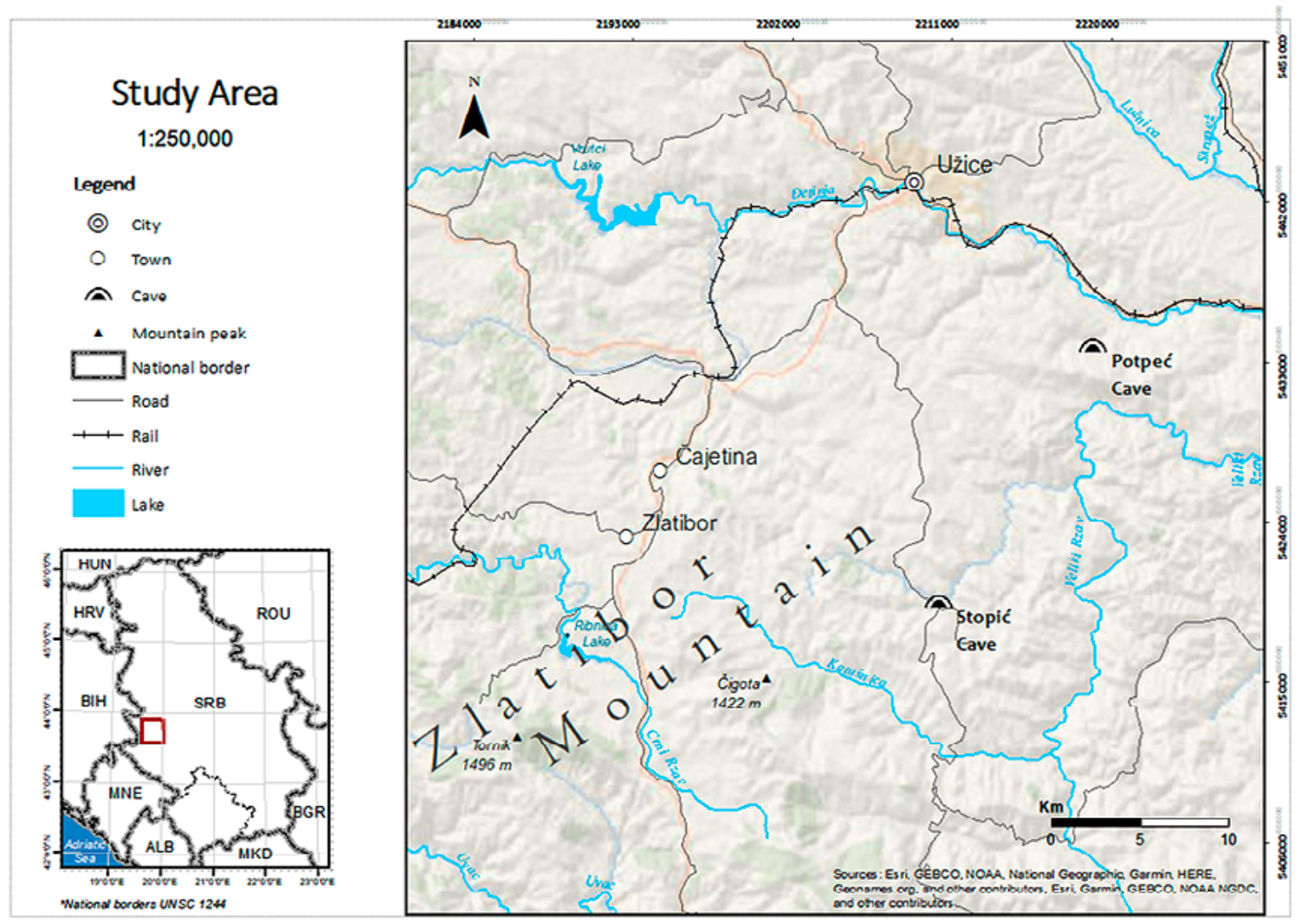

Figure 3. Location of the case study

70o steps. It is assumed that the cave was a human habitat even during the Neolithic period. Archaeological remains were found in the cave: ceramics, processed deer horns and flint tools.

From the cave, water is flowing and in front of the cave there are two springheads, which together build Petnica river. After $2 \mathrm{~km}$ of the flow, Petnica stream flows into Đetinja river, as her right tributary. From the highway and railway Požega - Užice, i.e. Belgrade - Adriatic Sea, Potpećka cave is about $2.5 \mathrm{~km}$ away. Cave is located $14 \mathrm{~km}$ away from Užice city in south-east direction, from Požega city $12 \mathrm{~km}$ in the southwest direction and from Belgrade (Serbian capital) $188 \mathrm{~km}$ (Terzić, 2008).

The cave consists of two main networks of cave hallways and channels: Upper and Lower cave. The entrance sections of both of these cave channels were connected into one - the Main cave hallway.

\section{Methodology}

The methodology of this study is based upon the modified geosite assessment model (M-GAM), developed by Tomić and Božić (2014). This method is based on geosite assessment model (GAM), developed by Vujičić et al., (2011). The GAM model was developed under the influence of previous geosite assessment methods developed by different authors (Bruschi, Cendrero, 2005; Coratza, Giusti, 2005; Erhartič, 2010; Hose, 1997; Pereira et al., 2007; Pralong, 2005; Rey- 
nard, 2008; Reynard et al., 2007; Serrano, González-Trueba, 2005; Zouros, 2007). The M-GAM represents a unique way of using the GAM model. It combines the opinion of both sides, tourists and experts, in such a way that neither side is favoured in the assessment process. It has been successfully tested and applied numerous times for the assessment of various geosites (Antić, Tomić, 2017; Boškov et al., 2015; Božić et al., 2014; Božić, Tomić, 2015; Tičar et al., 2018; Tomić et al., 2015; Tomić et al., 2019; Vukoičić et al., 2018; Antić et al., 2019).

The M-GAM model consists of two key indicators: Main Values and Additional Values, which are further divided into 12 and 15 indicators respectively, each individually marked from o to 1 . This division is made due to two general kinds of values: main - that are mostly generated by geosite's natural characteristics; and additional - that are mostly human-induced and generated by modifications for its use by visitors. The Main Values comprise three groups of indicators: scientific/educational (VSE), scenic/aesthetical values (VSA) and protection (VPr) while the Additional Values are divided into two groups of indicators, functional (VFn) and touristic values (VTr). The Main and Additional Values are more detailed presented in table 1. In total sum, there are 12 subindicators of Main Values, and 15 subindicators of Additional Values which are graded from o to 1 that define GAM as a simple equation:

$G A M=M V+A V$

where $M V$ and $A V$ represent symbols for Main and Additional Values. Since Main and Additional Values consist of three or two groups of subindicators, we can derive these two equations:

$M V=V S E+V S A+V P r$,

$A V=V F n+V T r$,

Now that we know that each group of indicators consists of several subindicators, equations (2) and (3) can be written as follows:

$$
\begin{aligned}
& M V=V S E+V S A+V \operatorname{Pr}=\sum_{i=1}^{12} \operatorname{SIM} V_{i} \quad \text { where } 0 \leq S I M V_{i} \leq 1 \\
& A V=V F n+V T r=\sum_{j=1}^{15} \operatorname{SIA} V_{i} \quad \text { where } 0 \leq S I A V_{i} \leq 1
\end{aligned}
$$

Here, $S I M V_{i}$ and $S I A V_{j}$ represent 12 subindicators of Main Values $(i=1, \ldots, 12)$ and 15 subindicators $(j=1, \ldots, 15)$ of Additional Values.

Based on the assessment results, a matrix of Main (X axes) and Additional Values (Y axes) is created (Figure $X)$. The matrix is divided into nine fields represented with $Z(i, j)$, $(i, j=1,2,3)$. Depending on the final score, each geosite will fit into a certain field. For example, if a geosite's Main Values are 7 and additional are 4, the geosite will fit into the Z21 field which clearly indicates a medium level of Main and a low level of Additional Values.

While in GAM all grades for each subindicator are given by experts M-GAM, focuses not only on the expert's opinion but also on the opinion of visitors and tourists regarding the importance of each indicator in the assessment process. 
Visitor inclusion in the assessment process is done through a survey where each respondent is asked to rate the importance ( $I m$ ) of all 27 subindicators (from o.oo to 1.0o) in the M-GAM model (Table 2). The importance factor (Im) gives visitors the opportunity to express their opinion about each subindicator in the model and how important it is for them when choosing and deciding between several geosites that they wish to visit. After each respondent rates the importance of every subindicator, the average value of each subindicator is calculated and the final value of that subindicator is the importance factor. Afterwards, the value of the importance factor $(\mathrm{Im})$ is multiplied with the value that was given by experts (also from o.oo to 1.0o) who evaluate the current state and value of subindicators (Table 2).

This is done for each subindicator in the model after which the values are added up according to M-GAM equation but this time with more objective and accurate final results due to the addition of the importance factor (Im). This parameter is determined by visitors who rate it in the same way as experts rate the subindicators for Main and Additional Values by giving them one of the following numerical values: $0.00,0.25,0.50,0.75$ and 1.00 , marked as points. The importance factor $(I m)$ is defined, as:

$$
I m=\frac{\sum_{k=1}^{K} I v_{k}}{K}
$$

Where $I v_{k}$ is the assessment/score of one visitor for each subindicator and $K$ is the total number of visitors. Note that the Im parameter can have any value in the range from o.oo to 1.oo.

Finally, the modified GAM equation is defined and presented in the following form:

$M-G A M=M V+A V$

$$
M V=\sum_{i=1}^{n} \operatorname{Im}_{i} \cdot M V i
$$

$$
A V=\sum_{i=1}^{n} \operatorname{Im}_{j} \cdot A V_{j}
$$

As it can be seen from the M-GAM equation, the value of the importance factor (Im), which is rated by visitors (for each subindicator separately) is multiplied with the value given by experts (also separately for each subindicator). This is done for each subindicator in the model. Therefore, the values of $M-G A M$ sub-indicators are always equal or less than GAM values. 
Table 1. The structure of Geosite Assessment Model (GAM)

\begin{tabular}{|c|c|}
\hline Indicators/Subindicators & Description \\
\hline \multicolumn{2}{|l|}{ Main values $(M V)$} \\
\hline \multicolumn{2}{|c|}{ Scientific/Educational value (VSE) } \\
\hline Rarity & Number of closest identical sites \\
\hline Representativeness & Didactic and exemplary characteristics of the site due to its own quality and general configuration \\
\hline $\begin{array}{l}\text { Knowledge on geoscientific } \\
\text { issues }\end{array}$ & Number of written papers in acknowledged journals, thesis, presentations and other publications \\
\hline Level of interpretation & $\begin{array}{l}\text { Level of interpretive possibilities on geological and geomorphologic processes, phenomena and } \\
\text { shapes and level of scientific knowledge }\end{array}$ \\
\hline \multicolumn{2}{|l|}{ Scenic/Aesthetic (VSA) } \\
\hline Viewpoints & $\begin{array}{l}\text { Number of viewpoints accessible by a pedestrian pathway. Each must present a particular angle of } \\
\text { view and be situated less than } 1 \mathrm{~km} \text { from the site. }\end{array}$ \\
\hline Surface & Whole surface of the site. Each site is considered in quantitative relation to other sites \\
\hline $\begin{array}{l}\text { Surrounding landscape } \\
\text { and nature }\end{array}$ & $\begin{array}{l}\text { Panoramic view quality, presence of water and vegetation, absence of human-induced } \\
\text { deterioration, vicinity of urban area, etc. }\end{array}$ \\
\hline $\begin{array}{l}\text { Environmental fitting } \\
\text { of sites }\end{array}$ & Level of contrast to the nature, contrast of colors, appearance of shapes, etc. \\
\hline \multicolumn{2}{|l|}{ Protection (VPr) } \\
\hline Current condition & Current state of geosite \\
\hline Protection level & Protection by local or regional groups, national government, international organizations, etc. \\
\hline Vulnerability & Vulnerability level of geosite \\
\hline Suitable number of visitors & $\begin{array}{l}\text { Proposed number of visitors on the site at the same time, according to surface area, vulnerability } \\
\text { and current state of geosite }\end{array}$ \\
\hline \multicolumn{2}{|l|}{ Additional values $(A V)$} \\
\hline \multicolumn{2}{|l|}{ Functional values $(V F n)$} \\
\hline Accessibility & Possibilities of approaching to the site \\
\hline Additional natural values & Number of additional natural values in the radius of $5 \mathrm{~km}$ (geosites also included) \\
\hline $\begin{array}{l}\text { Additional anthropogenic } \\
\text { values }\end{array}$ & Number of additional anthropogenic values in the radius of $5 \mathrm{~km}$ \\
\hline Vicinity of emissive centers & Closeness of emissive centers \\
\hline $\begin{array}{l}\text { Vicinity of important } \\
\text { road network }\end{array}$ & Closeness of important road networks in the in radius of $20 \mathrm{~km}$ \\
\hline Additional functional values & Parking lots, gas stations, mechanics, etc. \\
\hline \multicolumn{2}{|l|}{ Touristic values (VTr) } \\
\hline Promotion & Level and number of promotional resources \\
\hline Organized visits & Annual number of organized visits to the geosite \\
\hline Vicinity of visitors centers & Closeness of visitor center to the geosite \\
\hline Interpretative panels & $\begin{array}{l}\text { Interpretative characteristics of text and graphics, material quality, size, fitting to surroundings, } \\
\text { etc. }\end{array}$ \\
\hline Number of visitors & Annual number of visitors \\
\hline Tourism infrastructure & $\begin{array}{l}\text { Level of additional infrastructure for tourist (pedestrian pathways, resting places, garbage cans, } \\
\text { toilets etc.) }\end{array}$ \\
\hline Tour guide service & If exists, expertise level, knowledge of foreign language(s), interpretative skills, etc. \\
\hline Hostelry service & Hostelry service close to geosite \\
\hline Restaurant service & Restaurant service close to geosite \\
\hline
\end{tabular}




\begin{tabular}{|c|c|c|c|c|c|}
\hline & \multicolumn{5}{|l|}{ Grades (0.00-1.00) } \\
\hline & 0.00 & 0.25 & 0.50 & 0.75 & 1.00 \\
\hline 1. & Common & Regional & National & International & The only occurence \\
\hline 2. & None & Low & Moderate & High & Utmost \\
\hline 3. & None & Local publications & Regional publications & National publications & $\begin{array}{l}\text { International } \\
\text { publications }\end{array}$ \\
\hline 4. & None & $\begin{array}{l}\text { Moderate level of } \\
\text { processes but hard } \\
\text { to explain to non } \\
\text { experts }\end{array}$ & $\begin{array}{l}\text { Good example of } \\
\text { processes but hard to } \\
\text { explain to non experts }\end{array}$ & $\begin{array}{l}\text { Moderate level of } \\
\text { processes but easy to } \\
\text { explain to common } \\
\text { visitor }\end{array}$ & $\begin{array}{l}\text { Good example of } \\
\text { processes and easy to } \\
\text { explain to common } \\
\text { visitor }\end{array}$ \\
\hline 5. & None & 1 & 2 to 3 & 4 to 6 & More than 6 \\
\hline 6. & Small & - & Medium & - & Large \\
\hline 7. & - & Low & Medium & High & Utmost \\
\hline 8. & Unfitting & - & Neutral & - & Fitting \\
\hline 9. & $\begin{array}{l}\text { Totally damaged } \\
\text { (as a result of } \\
\text { human activities) }\end{array}$ & $\begin{array}{l}\text { Highly damaged (as } \\
\text { a result of natural } \\
\text { processes) }\end{array}$ & $\begin{array}{l}\text { Medium damaged } \\
\text { (with essential } \\
\text { geomorphologic features } \\
\text { preserved) }\end{array}$ & Slightly damaged & No damage \\
\hline 10. & None & Local & Regional & National & International \\
\hline 11. & $\begin{array}{l}\text { Irreversible (with } \\
\text { possibility of } \\
\text { total loss) }\end{array}$ & $\begin{array}{l}\text { High (could be easily } \\
\text { damaged) }\end{array}$ & $\begin{array}{l}\text { Medium (could be } \\
\text { damaged by natural } \\
\text { processes or human } \\
\text { activities) }\end{array}$ & $\begin{array}{l}\text { Low (could be damaged } \\
\text { only by human } \\
\text { activities) }\end{array}$ & None \\
\hline 12. & 0 & 0 to 10 & 10 to 20 & 20 to 50 & More than 50 \\
\hline 13. & Inaccessible & $\begin{array}{l}\text { Low (on foot with } \\
\text { special equipment } \\
\text { and expert guide } \\
\text { tours) }\end{array}$ & $\begin{array}{l}\text { Medium (by bicycle and } \\
\text { other means of man- } \\
\text { powered transport) }\end{array}$ & High (by car) & Utmost (by bus) \\
\hline 14. & None & 1 & 2 to 3 & 4 to 6 & More than 6 \\
\hline 15. & None & 1 & 2 to 3 & 4 to 6 & More than 6 \\
\hline 16. & $\begin{array}{l}\text { More than } 100 \\
\text { km }\end{array}$ & 100 to $50 \mathrm{~km}$ & 50 to $25 \mathrm{~km}$ & 25 to $5 \mathrm{~km}$ & Less than $5 \mathrm{~km}$ \\
\hline 17. & None & Local & Regional & National & International \\
\hline 18. & None & Low & Medium & High & Utmost \\
\hline 19. & None & Local & Regional & National & International \\
\hline 20. & None & Less than 12 per year & 12 to 24 per year & 24 to 48 per year & More than 48 per year \\
\hline 21. & More than $50 \mathrm{~km}$ & 50 to $20 \mathrm{~km}$ & 20 to $5 \mathrm{~km}$ & 5 to $1 \mathrm{~km}$ & Less than $1 \mathrm{~km}$ \\
\hline 22. & None & Low quality & Medium quality & High quality & Utmost quality \\
\hline 23. & None & Low (less than 5000) & $\begin{array}{l}\text { Medium (5001 to } 10 \\
\text { 000) }\end{array}$ & $\begin{array}{l}\text { High (10 } 001 \text { to } 100 \\
000)\end{array}$ & $\begin{array}{l}\text { Utmost (more than } 100 \\
000 \text { ) }\end{array}$ \\
\hline 24. & None & Low & Medium & High & Utmost \\
\hline 25. & None & Low & Medium & High & Utmost \\
\hline 26. & More than $50 \mathrm{~km}$ & $25-50 \mathrm{~km}$ & $10-25 \mathrm{~km}$ & $5-10 \mathrm{~km}$ & Less than $5 \mathrm{~km}$ \\
\hline 27. & More than 25 km & $10-25 \mathrm{~km}$ & $10-5 \mathrm{~km}$ & $1-5 \mathrm{~km}$ & Less than $1 \mathrm{~km}$ \\
\hline
\end{tabular}

Source: Vujičić et al., 2011. 
In their research about different geotouristic segments, Božić and Tomić (2015) conducted a survey and calculated the importance factor for each subindicator in the M-GAM model. Therefore, the values of the importance factor in this paper have been adopted from the mentioned paper.

\section{Results and Discussion}

This chapter will present the tourist evaluation of the caves in the Zlatibor county, using the M-GAM model. A detailed analysis of the results is presented, which includes the evaluation of the main and additional values of the geosites. The main values include 12 subindicators related to the scientific/educational values, landscape/aesthetic values and protection of geosites. Additional values comprise of 15 subindicators that include functional and tourist values of geosites.

Subindicators of scientific values are evaluated differently, which is a consequence of the tourist diversity of the explored speleological area. Rarity of caves was evaluated with the score of 0.50 , because they are rare in a regional context. The Stopića cave, with its rimstone pools, is a very rare phenomenon, but when we consider the rarity of speleological objects, these geosites are regional occurrences. Representativeness of Stopića cave was rated with 0.75, and Potpećka cave with 0.5. The Stopića cave has good didactic characteristics based on its own quality and general configuration, while Potpećka cave has a medium quality of representativeness and less cave jewellery. Cave exploration is also different. The Stopića cave was explored at the national level, while Potpećka Cave was explored at the regional level. The national level of exploration of the Stopića cave is mostly related to the publications of the Geographical Institute "Jovan Cvijić" in Belgrade. From the beginning of the 2oth century to this day, many scientists have been exploring the cave and they have written about their observations in numerous publications. As for the interpretation, both caves have the possibility of easy explanation for the average visitor, with Stopića cave containing good geological and geomorphologic processes, while Potpećka cave contains the average quality of these processes.

If we take a look at landscape and aesthetic values, the fitting of the caves into the environment is best rated (1.0o). Both caves are located in a unique natural setting, with rich vegetation and diverse fauna. It should be noted that, when it comes to caves, the inner look and geomorphological values are of utmost importance. Based on the outer appearance, the true value of the cave cannot be estimated. The surface area of both caves is medium. Therefore, the surface subindicator was given a score of 0.50. In Serbia, there are caves with a longer and shorter main channel (the one for the tourists' movements), but also there are caves that have channels, which are only a few hundred meters long. Those caves would be evaluated with the lowest grade, while caves that have channels longer than 2000 meters would be evaluated with the highest grade. Landscape subindicator and the natural environment are highly rated (0.75). Caves are located in a rural setting surrounded by villages. Around the Stopića cave there are forest slopes of the Zlatibor mountain, which significantly enrich the tourists experience. It is generally known that caves are located in hard-to-reach places, given the specific conditions under which they occur. Based on this, the fitting of the analyzed caves in the environment received the highest score (1.0o). 
Table 2. Subindicator values given by experts for each analysed geosite

\begin{tabular}{|c|c|c|c|c|c|}
\hline \multirow{2}{*}{$\begin{array}{l}\text { Main } \\
\text { Indicators/subindicators }\end{array}$} & \multicolumn{2}{|c|}{ Grades } & \multirow{2}{*}{ Im } & \multicolumn{2}{|c|}{ Total value } \\
\hline & Stopića cave & Potpećka cave & & Stopića cave & Potpećka cave \\
\hline \multicolumn{6}{|l|}{ Main values } \\
\hline \multicolumn{6}{|l|}{ I Scientific/educational values (VSE) } \\
\hline Rarity (SIMV1) & 0.5 & 0.5 & 0.89 & 0.44 & 0.44 \\
\hline Representativeness (SIMV2) & 0.75 & 0.5 & 0.79 & 0.59 & 0.39 \\
\hline Knowledge on geo-scientific issues (SIMV3) & 0.75 & 0.5 & 0.45 & 0.33 & 0.22 \\
\hline Level of interpretation (SIMV4) & 1 & 0.75 & 0.85 & 0.85 & 0.63 \\
\hline \multicolumn{6}{|l|}{ II Scenic/aesthetic values (VSA) } \\
\hline Viewpoints (SIMV5) & 0.25 & 0.25 & 0.79 & 0.19 & 0.19 \\
\hline Surface (SIMV6) & 0.5 & 0.5 & 0.54 & 0.27 & 0.27 \\
\hline Surrounding landscape and nature (SIMV7) & 0.75 & 0.75 & 0.95 & 0.71 & 0.71 \\
\hline Environmental fitting of sites (SIMV8) & 1 & 1 & 0.68 & 0.68 & 0.68 \\
\hline \multicolumn{6}{|l|}{ III Protection } \\
\hline Current condition (SIMV9) & 0.50 & 0.75 & 0.83 & 0.41 & 0.62 \\
\hline Protection level (SIMV10) & 0.75 & 0.75 & 0.76 & 0.57 & 0.57 \\
\hline Vulnerability (SIMV11) & 0.25 & 0.5 & 0.58 & 0.14 & 0.29 \\
\hline Suitable number of visitors (SIMV12) & 0.75 & 0.75 & 0.42 & 0.31 & 0.31 \\
\hline \multicolumn{6}{|l|}{ Additional values } \\
\hline \multicolumn{6}{|l|}{ I Functional values } \\
\hline Accessibility (SIAV1) & 1 & 0.75 & 0.75 & 0.75 & 0.56 \\
\hline Additional natural values (SIAVZ) & 0 & 0.25 & 0.71 & 0 & 0.17 \\
\hline Additional anthropogenic values (SIAV3) & 0 & 0.5 & 0.70 & 0 & 0.35 \\
\hline Vicinity of emissive centres (SIAV4) & 0.75 & 0.75 & 0.48 & 0.36 & 0.36 \\
\hline Vicinity of important road network (SIAV5) & 0.5 & 0.75 & 0.62 & 0.31 & 0.46 \\
\hline Additional functional values (SIAV6) & 0.25 & 0 & 0.59 & 0.14 & 0 \\
\hline \multicolumn{6}{|l|}{ II Tourist values } \\
\hline Promotion (SIAV7) & 0.5 & 0.5 & 0.85 & 0.42 & 0.42 \\
\hline Annual number of organised visits (SIAV8) & 1 & 0.5 & 0.56 & 0.28 & 0.28 \\
\hline Vicinity of visitors centres (SIAV9) & 0 & 0 & 0.87 & 0 & 0 \\
\hline Interpretive panels (SIAV10) & 0.75 & 0.25 & 0.81 & 0.60 & 0.20 \\
\hline Annual number of visitors (SIAV11) & 0.75 & 0.5 & 0.43 & 0.32 & 0.21 \\
\hline Tourism infrastructure (SIAV12) & 0.75 & 0 & 0.73 & 0.54 & 0 \\
\hline Tour guide service (SIAV13) & 0.75 & 0.5 & 0.87 & 0.65 & 0.43 \\
\hline Hostelry service (SIAV14) & 0.75 & 1 & 0.73 & 0.54 & 0.73 \\
\hline Restaurant service (SIAV15) & 0.5 & 1 & 0.78 & 0.39 & 0.78 \\
\hline
\end{tabular}

During the protection of the caves, the goal was to preserve essential geomorphologic characteristics. The study of Baker and Genty (1998) shows that the presence of tourists in the cave is damaging the natural atmosphere of the cave. Since Stopića cave is far more visited than Potpećka cave, a greater risk of damage exists. Many tourists degrade the interior of the caves (by throwing trash, destroying cave jewellery, etc.). For this reason, it is necessary to have constant control of tourism activities by the cave management, i.e. responsible management, which will 
take care of preserving the natural values of the cave. One of the key tasks of the management is to respect the strategy for the protection of natural monuments. This includes preventing the degradation of nature and breaking the limits of the carrying capacity. Also, if visitors do not respect the rules of movement in the cave, they can endanger the cave jewellery. This is quite dangerous when it comes to rimstone pools in Stopića cave, as visitors like to climb on them to take photographs. Stopića cave has been protected since 1976. by the municipality of Čajetina. Today, Stopića cave is a protected natural good of exceptional importance, a monument of nature of the 1st category. In 1992, the Potpećka cave, on the proposal of the Institute for Nature Protection, in accordance with the Užice City Assembly, was placed under protection as a significant natural good. Both caves are now protected on a national level (o.75).

Indicators of additional values are functional and tourist values. Within the functional values, one of the crucial subindicators is accessibility. The Stopića cave can be reached by bus. However, from the parking to the cave, it is necessary to pass a considerable distance and height difference due to the very area on which the cave is located, which can be very difficult for people with health problems as well as the elderly. The path is adapted and equipped for tourists and there are benches and garbage cans, thus accessibility is given a rating of 1.oo. Furthermore, Potpećka cave cannot be reached by bus, but only by car. For this reason, this geosite was given a score of 0.75. Additional natural values of the Stopića cave are rated with lowest scores, because there is no additional natural value within the $5 \mathrm{~km}$ range. In the area of $11 \mathrm{~km}$ there is the Gostilje waterfall. Additional anthropogenic values of the Stopića cave are within a range of 12-15 km, which are the Outdoor museum "Staro selo" in Sirogojno, the Church of St. Petar and Pavle and the Knitting Museum in Sirogojno. Therefore, the Stopića cave was given the score of o.oo for these subindicators. Additional natural and anthropogenic values of the Potpećka cave were evaluated differently. The most important additional natural value is the river Petnica, which flows beneath the cave and close to Veliki Rzav river. The anthropogenic value of the Potpećka cave is located in its immediate vicinity, which is the Outdoor Museum of Terzića Avlija, located $2 \mathrm{~km}$ from the cave. This Outdoor Museum includes old wooden houses of Western Serbia from the 2oth century. It's significant that in this village, a large number of households engage in pottery, i.e. the production of baked clay goods. The proximity of the emissive centers is estimated to be high (0.75). Zlatibor mountain and tourist center is about $20 \mathrm{~km}$ away from the caves. Also, $35 \mathrm{~km}$ from the caves there is the city of Užice. The subindicator of the proximity of important roads is of regional character, because the regional road Ibar Highway, that connects Belgrade with Podgorica (Montenegro), is located $19 \mathrm{~km}$ from the caves.

It is significant that the Tourist Organization of Zlatibor promotes the Stopića cave on its website. The promotion of this cave is often done on national and international fairs. Conversely, Potpećka Cave has been neglected in promotional activities, both at the national and international level. Geotourism largely requires the promotion of geosites, because only with adequate promotion, tourists and the local community can have significant benefits. Top rated subindicators for tourist values are the subindicators organized visits and number of visitors per year. A large number of caves in Serbia do not keep records of tourist traffic, but that is not the case with Stopića cave. According to the data of the Tourism Organization of Zlatibor, in the last 10 years, the number of tourists has grown significantly and in 2017 amounts to 61262 visits, and in 2018, it's closer to 80 ooo tourists a year, which is an impressive result, in comparison to other Serbian caves. Currently, according to the number of visitors, Stopića cave is, along with Resavska cave, the most visited speleological object in Serbia. We can confirm with certainty that the annual number of organized visits is between 28 and 48. Potpećka cave has very few organized visits, as well as a small number of visitors per year. This geosite was given 
a score of 0.5 , which means that it has from 12 to 24 organized visits per year. It is necessary to improve the tourist traffic and tourist income of Potpećka cave, so that the speleotouristic offer of Western Serbia can have a better quality and more unique structure. The tourist infrastructure subindicator for the Potpećka cave does not have significant results. It was given a rating of 0.25 , because there are no other contents along with the pedestrian path in the cave, such as: ticket office, toilets, parking, souvenir shop, etc. The subindicator for the tour guide service is one of the most important for tourist visits. Tour guides that introduce visitors to the Stopića cave are trained to provide more detailed information about the cave and they speak two foreign languages, English and Russian, which earns them a rate of 0.75 . The guide service of the Potpećka cave offers only tours in Serbian and English language. For tour guides to possess quality interpretative skills, they need to know several other languages (German, French, Spanish etc.). That is why this cave was given a score of 0.50 for this subindicator. In the immediate vicinity of Stopića cave is the village of Rožanstvo. At only $4 \mathrm{~km}$ away, there are a few accommodation capacities, households "Melović" and "Mimov konak". Also, there are a couple of restaurants, the most famous of which is the "Lipov cvet". That is why the rate for accommodation and hospitality services is 0.75 . When it comes to Potpećka cave, in the vicinity of $2 \mathrm{~km}$, there are a number of households providing accommodation, and Terzića avlija, next to museum visits, offers authentic accommodation and food services. Because of these circumstances, Potpećka cave has the highest scores for hostelry and restaurant services.

After summarizing the results of the obtained values of the subindicators, the position of the caves can be determined in the M-GAM matrix. If we take the importance factor into account, we certainly get objective results and a more detailed position in the matrix.

Table 3. Overall ranking of the analyzed caves by M-GAM

\begin{tabular}{|l|c|c|c|c|c|}
\hline \multirow{2}{*}{ Geosite } & \multicolumn{2}{|c|}{ Main values } & \multicolumn{2}{c|}{ Additional values } & \multirow{2}{*}{ Field } \\
\cline { 2 - 5 } & VSE+VSA+VPr & $\Sigma$ & VFn+VTr & $\Sigma$ & Z22 \\
\hline Stopića cave & $2.21+1.85+1.43$ & 5.49 & $1.56+4.02$ & 5.58 & Z21 \\
\hline Potpećka cave & $1.68+1.85+1.79$ & 5.32 & $1.9+3.05$ & 4.95 & \multicolumn{2}{|c|}{ Z } \\
\hline
\end{tabular}

Certainly, the scientific, aesthetic and environmental values of the Stopića cave are paramount for speleotourism and geotourism development in Zlatibor county. It is certain that there is room for further exploration and arrangement of the pedestrian track above the rimstone pools, as well as above the waterfall "The Source of Life", which would make the visit to the cave itself more interesting and longer for tourists. When it comes to tourist values, in the last ten years, a lot has been done and built in accordance with the strategy of managing the Stopića cave, which is very important for geotourism development. Tourist organization of Zlatibor respects the strategy and significantly helps to improve and maintain the tourism infrastructure. What is remarkable is that the local population is engaged in the cave preservation and thus contributes to the local economy, by increasing tourist income.

The Potpećka cave is positioned at the very top of the field $Z_{21}$, at the border with the field $Z_{22}$. It can be concluded that this geosite can very quickly, with efficient management, move to the next field ( $\left.\mathrm{Z}_{22}\right)$ and thus get medium higher quality of the additional values. It is necessary to work more intensively on marketing strategies, as well as the development of other tourism strategies. The unified speleoturistic offer of Western Serbia could crucially influence the development of tourism in the regional sense. Therefore, a unique offer should be made, with rich spelological geotourism content. 


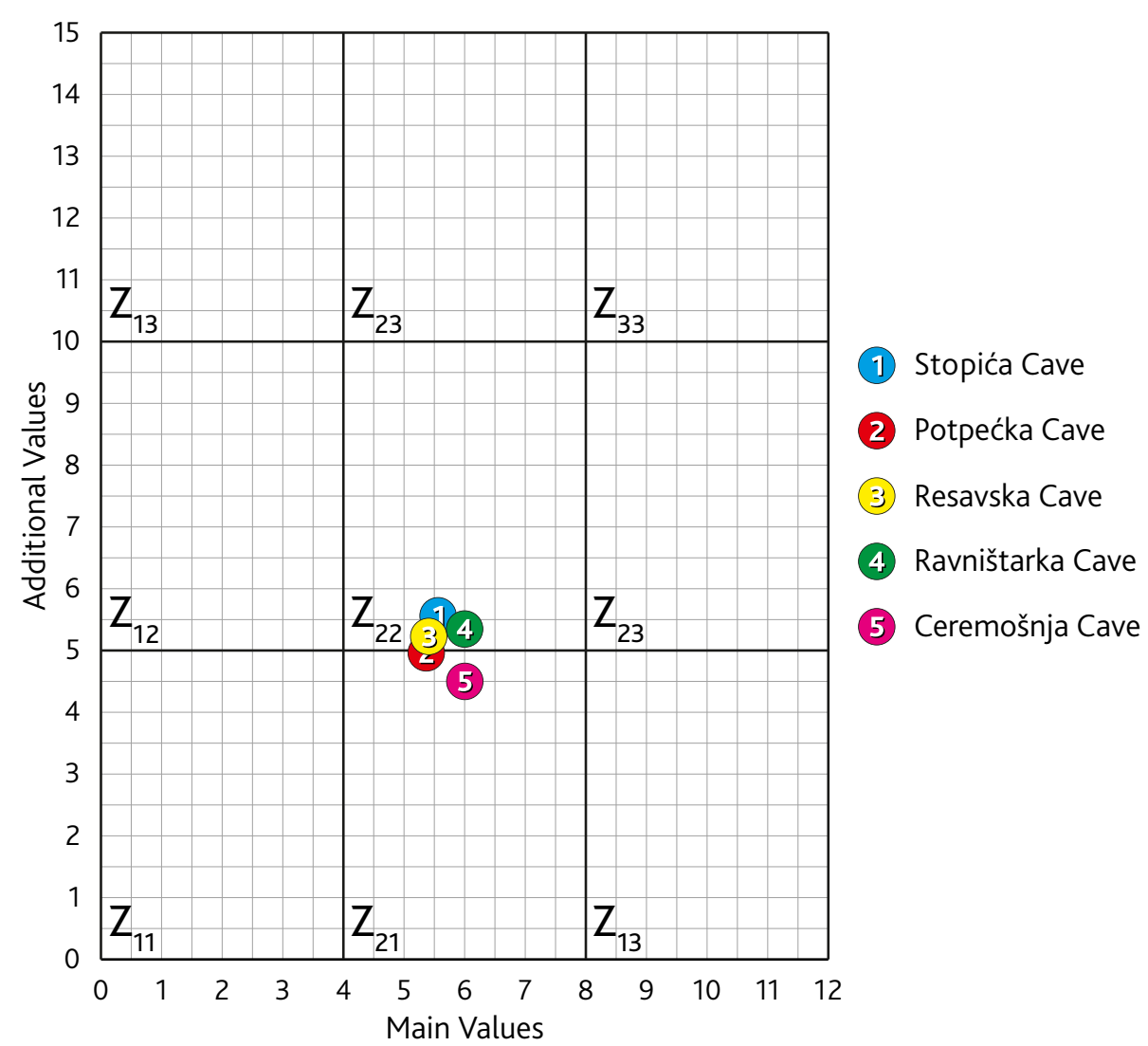

Figure 4. Position of the geosites in the M-GAM matrix

The study about cave tourism in Eastern Serbia by Tomić et al., (2019) has shown that the highest ranked cave is Resavska cave, which is positioned in the $Z_{22}$ field. If we compare those results with research results from this paper, it can be noted that the caves in the Zlatibor county have similar results in the M-GAM matrix as the highest ranked caves in Eastern Serbia. Stopića cave has similar results as Resavska cave, while Potpećka cave has similar results as Ceremošnja and Ravništarka cave. These data show us the degree of speleotourism development in different regions in Serbia. Although Western Serbia has less show caves than the Eastern region, the speleotourism development is quite similar.

Considering that the geological diversity of caves is adequate for tourism arrangement; it is certain that preservation of the current natural features is necessary. Their global recognition can certainly be enhanced if the level of protection has a higher level.

\section{Conclusion}

It is essential to recognize the necessity for the development of economically and environmentally sustainable forms of tourism and, as such, the development of geotourism is based on the development of various measures to regulate the conservation of geoheritage (Višnić et al., 2015). 
Exploring and assessing geotourism potential of Zlatibor county, by analyzing speleological objects was the main objective of this paper. The caves that are evaluated are representatives of speleotourism tradition in western Serbia and, as such, they include attractive geomorphological features. By applying the M-GAM we determined that the current tourism development state of these two caves is different. Their difference is shown in many aspects of the model, including tourism infrastructure, tour guide service, accessibility, exploration etc. The most important difference is shown in tourist visitation. Stopića cave has far more visitors than the Potpećka cave and generally has a better management organization. Furthermore, the tourism offer of Stopića cave includes better quality experience for visitors than Potpećka cave. The position of the caves in the M-GAM matrix reveals these differences and thus presents the state of their main and additional values. Although, the main values of the cave are not high, it is important to point out the uniqueness of rimstone pools in this cave. Considering the results of Stopića cave, it can be concluded that the cave needs more promotion, investments in tourism infrastructure and hostelry and restaurant services. On the other hand, Potpećka cave has the same quality level of main values like the Stopića cave, but it has lower additional values. These results show that necessary measures for speleotourism improvement must be focused on this cave. There are many aspects of this geosite that need to be improved, as we mentioned earlier in this paper. Nevertheless, one important subindicator of Potpećka cave was evaluated with highest score and that is hostelry and restaurant services, which represent a great complementary value.

The speleological approach for geotourism development in Zlatibor county is an authentic way to promote geoheritage and geoscience. Both, geotourism and speleotourism have a strong connection with the tourism market of this region. Therefore, these caves are constantly present in the regional tourism offers. The vicinity of Zlatibor mountain and Zlatibor tourist center allows many tourists to visit these caves. In the future this factor can be crucial for further geotourism development with speleological and geomorphological motives.

\section{References}

Antić, A., Tomić, N. 2017. Geoheritage and geotourism potential of the Homolje area (eastern Serbia). Acta Geoturistica 8(2), 67-78.

Antić, A., Tomić, N., Marković, S..B. 2019. Karst geoheritage and geotourism potential in the Pek River lower basin (Eastern Serbia). Geographica Pannonica 23(1), 32-46.

Baker, A., Genty, D. 1998. Environmental pressures on conserving cave speleothems: effects of changing surface land use and increased cave tourism. Journal of Environmental Management 53(2), 165-175.

Božić, S., Tomić, N. 2015. Canyons and gorges as potential geotourism destinations in Serbia: comparative analysis from two perspectives - general geotourists' and pure geotourists'. Open Geosciences 7, 531-546.

Božić, S., Tomić, N., Pavić, D. 2014. Canyons as potential geotourism attractions of Serbia comparative analysis of Lazar and Uvac canyons by using M-GAM model. Acta Geoturistica 5(2), 18-30.

Boškov, J., Kotrla, S., Jovanović, M., Tomić, N., Lukić, T., Rvović, I. 2015. Application of the preliminary geosite assessment model (GAM): the case of the Bela Crkva municipality (Vojvodina, North Serbia). Geographica Pannonica 19(3), 146-152.

Bruschi, V. M., Cendrero, A. 2005. Geosite evaluation. Can we measure intangible values? Il Quaternario 18(1), 293-306. 
Coratza, P., Giusti, C. 2005. Methodological proposal for the assessment of the scientific quality of geomorphosites. Il Quaternario 18(1), 307-313.

Cigna A., Burri, E. 20oo. Development, management and economy of show caves. International Journal of Speleology 29(1), 1-27.

Dowling, R. K. 2013. Global geotourism-an emerging form of sustainable tourism. Czech Journal of Tourism 2(2), 59-79.

Erhartič, B. 2010. Geomorphosite assessment. Acta Geographica Slovenica 50(2), 295-319.

Gurnee, R., Gurnee, J. 1981. The study report on the development of Harrison Cave, Barbados, West Indies. Atti Conv. Int. Grotte Turistiche, Borgio Verezzi 10(1), 101-107.

Hose, T. A. 1997. Geotourism - selling the earth to Europe. August Aimé Balkema, Rotterdam.

Lobo, H. A. S., Moretti, E. C. 2009. Tourism in caves and the conservation of the speleological heritage: the case of Serra da Bodoquena (Mato Grosso do Sul State, Brazil). Acta Carsologica, 38(2-3).

Newsome, D., Dowling, R. K. (Eds.) 2006. Geotourism. Elsevier, Oxford.

Pralong, J. P. 2005. A method for assessing the tourist potential and use of geomorphological sites. Géomorphologie: Relief, processus, environnement 3, 189-196. doi:10.40oo/geomorphologie.350

Pereira, P., Pereira, D., Caetano Alves, M. I. 2007. Geomorphosite assessment in Montesinho Natural Park (Portugal). Geographica Helvetica 62, 150-168.

Reynard, E. 2008. Scientific research and tourist promotion of geomorphological heritage. Geografia fisica e dinamica quaternaria 31(2), 225-230.

Reynard, E., Fontana, G., Kozlik, L., Scapozza, C. 2007. A method for assessing "scientific“ "additional values“ of geomorphosites. Geographica Helvetica 62(3), 148-158.

Serrano, E., González-Trueba, J. J. 2005. Assessment of geomorphosites in natural protected areas: the Picos de Europa National Park (Spain). Géomorphologie. Formes, processus, environnement 3, 197-208.

Terzić, Đ. 2008. Tourist potential of Podpećka cave. Bachelor thesis. Faculty of Sciences. University of Novi Sad. (in Serbian)

Tomić, N., Antić, A., Marković, S. B., Đorđević, T., Zorn, M., Valjavec, M. B. 2019. Exploring the Potential for Speleotourism Development in Eastern Serbia. Geoheritage 11(2), 359-369.

Tomić, N., Božić, S. 2014. A modified geosite assessment model (MGAM) and its application on the Lazar Canyon area (Serbia). International Journal of Environmental Research 8(4), 1041-1052.

Tomić, N. 2011. The potential of Lazar Canyon (Serbia) as a geotourism destination: inventory and evaluation. Geographica Pannonica 15(3), 103-112.

Tomić, N., Marković, S.B., Korać, M., Mrđić, N., Hose, T.A., Vasiljević, Dj.A., Jovičić, M., Gavrilov, M.B. 2015. Exposing mammoths: from loess research discovery to public palaeontological park. Quaternary International 372, 142-150.

Tičar, J., Tomić, N., Breg Valjavec, M., Zorn, M., Marković, S.B., Gavrilov, M. B. 2018. Speleotourism in Slovenia: balancing between mass tourism and geoheritage protection. Open Geosciences 10, 344-357.

Višnić, T., Began, M. 2015. Geoheritage sites in the function of geotourism development in the Republic of Serbia. Synthesis: International Scientific Conference of IT and Business Related Research, (552-557). Belgrade: Singidunum University.

Višnić, T., Spasojević, B., Vujičić, M. 2016. The potential for geotourism development on the Srem Loess Plateau based on a preliminary geosite assessment model (GAM). Geoheritage $8(2), 173-180$. 
Vujičić, M., Vasiljević, Đ., Marković S., Hose T. A., Lukić, T., Hadžić, O., Janićević, S. 2011. Preliminary geosite assessment model (GAM) and its application on Fruška Gora Mountain, potential geotourism destination of Serbia. Acta Geographica Slovenica 51, 361-377.

Vukoičić, D., Milosavljević, S., Valjarević, A., Nikolić, M., Srećković-Batoćanin, D. 2018. The evaluation of geosites in the territory of National park „Kopaonik“ (Serbia). Open Geosciences 10, 618-633. https://doi.org/10.1515/geo-2018-0049

Zouros, N. C. 2007. Geomorphosite assessment and management in protected areas of Greece. The case of the Lesvos island coastal geomorphosites. Geographica Helvetica 62, 169-180.

Đurović, P., Mijović, D. 2006. Geoheritage of Serbia-Representative of its total geodiversity. Collection of papers - Faculty of Geography at the University of Belgrade 54, 5-18.

Čumić, D. 2010. Tourist potential of Stopića cave. Bachelor thesis. Faculty of Sciences. University of Novi Sad. (in Serbian) 